\title{
Two-place Activity Predicates in Persian
}

\author{
Vali Rezai \\ Dept. of Linguistics, University of Isfahan, Isfahan, Iran \\ Email: vali.rezai@fgn.ui.ac.ir
}

\begin{abstract}
Some syntacticians claim that a non-referential second argument of an activity predicate expresses an intrinsic aspect of the meaning of the verb and does not refer specifically to any participants in the event denoted by the verb. The aim of this paper is to examine activity predicates in Persian to see whether they follow this proposal or not. Presenting the properties of two-place activity predicates in Persian, and their accomplishment counterparts, I argue that the second argument in activity verbs of consumption, creation, performance, etc. is an inherent argument of the predicate. Indeed, they are part of the predicate, rather than the participants in the event. Moreover, it is shown that if the second argument takes a referentiality marker, the verb class is changed to accomplishment. Finally, it is concluded that Persian supports the RRG treatment for two-place activity predicates.
\end{abstract}

Index Terms — activity predicates, accomplishment, Persian, Role and Reference Grammar

\section{INTRODUCTION}

Activity predicates have unique syntactic properties among other predicate classes depending upon whether their second arguments are referential or not. VanValin and LaPolla (1997) claim that when the second argument of a two-place activity predicate is non-referential or non-specific, it has an activity interpretation. On the other hand, when these predicates take a specific or referential second argument they will become accomplishments. Therefore, the four basic classes of verbs (state, achievement, accomplishment and activity) are augmented by a fifth class, active accomplishment (VanValin, 2005, p.32). Indeed, telic uses of activity verbs change them to accomplishments. This verb class alternation can be shown by the following two English sentences:

(1) (a) John ate fish.

(b) John ate the fish.

In (1.a) the action of eating fish has no inherent temporal boundary. However, in (1.b), once the fish is gone, the act of eating is done. According to VanValin (2005) the non-specific second arguments of activity verbs like eat are inherent arguments which express an intrinsic aspect of the meaning of the verbs and don't refer specifically to any participants in the event denoted by the verb. VanValin and LaPolla(1997) regard this difference between predicates such as (1.a) and (1.b) as a piece of evidence for an Aktionsart alternation and a mismatch between syntactic and semantic transitivity.

In this paper, I will examine activity predicates of Persian within the framework of RRG to see whether they follow the special treatment of this theory of grammar or not. In section 2, I introduce the theory of Role and Reference Grammar. A brief review of verb classification in RRG will be presented and I show that tests for determining activity predicates in this theory work for Persian unexceptionally. In section 3, I investigate the properties of second arguments in Persian activity predicates and present evidence which justify the proposal of VanValin and LaPolla. It will be shown that two place activity verbs follow RRG's assumptions. Evidence in support of this analysis from researches done by other Iranian linguists working with different syntactic theories will be presented in section 4 . Section 5 is devoted to transitivity in two-place activity predicates in Persian. I will show that Persian supports the contrast between S-transitivity and M-transitivity. Ultimately, conclusions will be presented in section 6 .

\section{INTRODUCING ROLE AND REFERENCE GRAMMAR}

RRG is a moderate functionalist theory. In this theory, syntax is neither autonomous, as in transformational grammar, nor identical with semantics, as in generative semantics. What distinguishes the RRG conception from the standard formalist one is the conviction that grammatical structure can only be understood and explained with reference to its semantic and communicative functions.Indeed, RRG grew out of an attempt to answer two basic questions:

1. What would linguistic theory look like if it were based on the analysis of Lakhota, Tagalog and Dyirbal, rather than on the analysis of English?

2. How can the interaction of syntax, semantics and pragmatics in different grammatical systems best be captured and explained? VanValin (2005, p.1)

The latest version and the most comprehensive presentation of this theory is discussed in VanValin and LaPolla (1997) and Van Valin(2005). RRG postulates four grammatical representations for each sentence. These are 'Linking from Semantics to Clause Structure', 'Constituent Projection', 'Operator Projection', and 'Focus Structure Projection'.

The RRG theory posits only a single level of syntactic representation for a sentence which is mapped directly into the semantic representation of the sentence. VanValin (2005, p.2) sketch the organization of RRG as the following figure. 


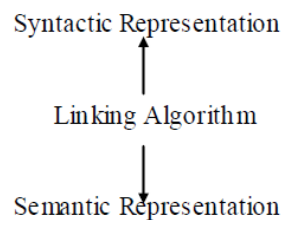

The syntactic and semantic tests proposed by Dowty(1979) are used in a modified form in RRG. This set of tests will isolate specific features in order to systematically classify the verbs of any language with minor language specific adjustments. In RRG, Aktionsart is the term used for the inherent temporal properties of verbs. Examples of English verbs fitting each of the four categories are given as follows in the literature (Foley and VanValin 1984, VanValin 1999d, Wyngaerd 2001, among others).

(3.1) a. States: be sick, know, believe, love, fear, have

b. Achievements: pop, explode, collapse, die, receive

c. Accomplishments: melt, freeze, learn, dry

d. Activities: walk, sing, study, think, swim, write, eat, read, march

TABLE 3.2

TESTS FOR DETERMINING AKTIONSART TYPE

\begin{tabular}{lllll}
\hline Criterion & States & Achievements & Accomplishments & Activities \\
\hline 1. Occurs with progressive & No & No & Yes & Yes \\
2. Occurs with adverbs like vigorously, actively, etc. & No & No & No & yes \\
3. Occurs with adverbs like quickly, slowly, etc. & No & No* & Yes & Yes \\
4. Occurs with X for an hour & Yes* & No & Irrelevant & Yes \\
5. Occurs with X in an hour & No & No* & Yes & No \\
\hline \hline
\end{tabular}

Having presented the above tests and their applications to different verb classes, I can now summarize tests for determining Persian verb classification as follows:

TABLE 3.3

TESTS FOR DETERMINING AKTIONSART TYPE IN PERSIAN.

\begin{tabular}{|c|c|c|c|c|}
\hline Criterion & States & Achievements & Accompl & Activities \\
\hline 1. Occurs with dar hâle or mašqule, 'in process of' & No & No & Yes & Yes \\
\hline 2. Occurs with bešeddat/bâjeddyat 'vigorously/actively.' & No & No & Yes & yes \\
\hline 3. Occurs with besor'at/âheste 'quickly/slowly' & No & No* & Yes & Yes \\
\hline 5. Occurs with dar yek sâ 'at 'in an hour' & No & No* & Yes & No \\
\hline
\end{tabular}

Having applied these five tests to Persian verbs, now, I can present a sample of each verb class in this language. However, it should be noted that the actual class of each verb is determined within the context in which it occurs. Examples of Persian verbs fitting each of four categories are given in the following table.

$\begin{array}{ll}\text { a. States } & \\ \text { dânestan } & \text { 'to know' } \\ \text { dâštan } & \text { 'to have' } \\ \text { dust dâštan } & \text { 'to like' } \\ \text { šenâxtan 1 } & \text { 'to know sb' } \\ \text { budan } & \text { 'to be' } \\ \text { tarsidan } & \text { 'to fear' } \\ \text { xâstan } & \text { 'to want' } \\ \text { didan } & \text { 'to see' } \\ \text { šenidan } & \text { 'to hear' } \\ & \\ \text { c.Accomplishments } \\ \text { sâxtan } & \text { 'to build' } \\ \text { dorost kardan } & \text { 'to make' } \\ \text { âb šodan } & \text { 'to melt' } \\ \text { âmuxtan } & \text { 'to learn' } \\ \text { xaridan } & \text { 'to buy' } \\ \text { âvordan } & \text { 'to bring' } \\ \text { suxtan } & \text { 'to burn' } \\ \text { yax zadan } & \text { 'to freeze' }\end{array}$

\begin{tabular}{ll}
\multicolumn{2}{c}{ b. Achievements } \\
tarakidan & 'to pop' \\
šenâxtan 2 & 'to recognize' \\
foru rixtan & 'to collapse' \\
residan & 'to arrive' \\
šekastan & 'to break' \\
mordan & 'to die' \\
koštan & 'to kill' \\
oftâdan & 'to fall'
\end{tabular}

$\begin{array}{ll}\begin{array}{ll}\text { d.Activities } \\ \text { davidan }\end{array} & \text { 'to run' } \\ \text { xordan } & \text { 'to eat' } \\ \text { xândan } & \text { 'to read / to recite' } \\ \text { qadam zadan } & \text { 'to walk' } \\ \text { nušidan } & \text { 'to drink' } \\ \text { guš kardan } & \text { 'to listen' } \\ \text { neveštan } & \text { 'to write' } \\ \text { šenâ kardan } & \text { 'to swim' } \\ \text { xandidan } & \text { 'to laugh' } \\ \text { gerye kardan } & \text { 'to cry' } \\ \text { raqsidan } & \text { 'to dance' }\end{array}$

\section{A. Semantic Roles}

The RRG theory of semantic roles is different from that of other theories, in that it posits two types of tiers of semantic roles. The first are specific thematic relations. The second are generalized semantic roles called semantic macroroles. 
These semantic relations are referred to as macroroles, since each of them subsumes a number of specific semantic relations. The terms to be used for these two arguments are 'Actor' and 'Undergoer', originally introduced in RRG byFoley and VanValin(1984)

\section{B. Transitivity}

Transitivity is traditionally defined in terms of the number of arguments a verb takes overtly in the syntax, but RRG makes a distinction between syntactic and semantic transitivity (VanValin and LaPolla, 1997). The syntactic valence of a verb is the number of overt morphosyntactically coded arguments it takes, while the semantic valence refers to the number of semantic arguments that it can take.

VanValin and LaPolla (1997, p.147) present the non-identity of semantic and syntactic valence in English verbs as the following table shows:

TABLE 3.6

NON-IDENTITY OF SEMANTIC AND SYNTACTIC VALENCE

\begin{tabular}{lll}
\hline Semantic valence & & Syntactic valence \\
\hline rain & 0 & 1 \\
die & 1 & 1 \\
eat & 2 & 1 or 2 \\
put & 3 & 3 or 2 \\
\hline
\end{tabular}

\section{ApPlicAtion OF RRG Tests to PERSIAN}

Since in this paper I deal with only activity predicates, these five tests will be applied to only this class of Persian verbs. As the above tests show activity verbs are compatible with all these tests except test 5 .

\section{A. Progressive Formation}

Persian does not have a distinct progressive aspectual form like English. Nevertheless there is another morphosyntactic construction which expresses progressive aspect (Dabirmoghaddam 1996). The expression dar hâle or mašqule 'in the process of' serves as the head of an EZAFE construction followed by the infinitive form of the verb as its dependent. The following sentences show that progressive construction is possible with activity verbs.

(3) Sinâ dar hâle davidan ast.

Sinâ in process run be-3sg

'Sina is running'

(4) ân pirmard dar hâle qadam zadan ast.

That old man in process step hit be-3sg.

'That old man is walking'

B. Occurrence with Adverbs like be šeddat 'vigorously' or bâjeddyat 'actively'.

RRG uses this test to distinguish states and achievements from accomplishments and activities. The following two sentences show that Persian activity verbs can occur with these two adverbs.

(5) Bačče- hâ bâ jeddeyat dars mi- xân- and.

Child- Pl actively lesson IMP-read- 3Pl

'The children study actively.'

(6) In bâzikon bešeddat mi- dav- ad.

This player vigorously IMP- run- $3 \mathrm{sg}$.

'This player runs vigorously.'

C. Occurrence with Adverbs like âheste, 'slowly' or be sor?at 'quickly'.

(7) ân -hâ âheste kâr mi- kon- and.

That -Pl slowly work IMP- do- $3 \mathrm{pl}$

'They work slowly.'

(8) U besor?at mi- nevešt.

3sg quickly IMP write-PAST

'He/she was writing quickly.'

D. Occurrence with (barây) yek sâ? at 'for an hour'

(9) Man (barây) yek sâ? at fekr kard- am.

I (for) one hour think do- past-1sg.

'I thought for an hour.'

(10) U har ruz yek sâ?at mi- davad.

3 sg every day one hour IMP-run- $3 \mathrm{sg}$

'He runs for an hour every day.' 
E. Occurrence with dar yek sâ? at 'in an hour'.

(11) * u har ruz dar yek sâ? at mi-davad.

3 sg every day in an hour IMP rfun-3sg.

*'He runs in an hour every day.'

As it can be seen from the above sentences (3-12), activity verbs in Persian follow the five tests presented above unexceptionally.

\section{Second Argument of Persian Activity Predicates}

The logical structure of activity predicates is represented in RRG as (13).

(13) do (x, [Predicaté (x) or (x,y)])

This logical structure tells us that an activity predicate may have one or two core arguments. The following two Persian sentences have only one argument.

(14) Ali mi-davad 'Ali runs'

(15) Mina mi-nevisad 'Mina writes'

Unlike (14-15) some activity verbs such as verbs of creation (neveštan 'to write' sâxtan 'to make'), verbs of consumption (xordan 'to eat' nušidan 'to drink' kešidan 'to smoke') and verbs of performance (xândan, to read/to recite' kardan 'to do') may take a second argument. If these verbs have a non-referential or bare noun as their second argumens, they behave like activity predicates. But they behave like accomplishment predicates if their second arguments take a marker of specificity or quantity. The following sentences have an activity interpretation.

(16) Pesar-hâ še?r mi- xând- and. boy- $\mathrm{pl}$ poem IMP- read- 3sg. The boys were reading poetry.

(17) Ali nâme mi- nevis- ad. Ali letter IMP- write- 3sg

(18) ân mard sigâr mi- keš- ad.

That man cigarette IMP- somke- $3 \mathrm{sg}$

'That man smokes.'

The second arguments in the sentences (16-18) are non-referential. še?r, nâme and sigâr have no markers of referentiality or quantity. In fact, they are bare nouns.

Now, let's compare these sentences with (19-21) in which the second arguments have a marker of referentiality or quantity.

(19) Pesar -hâ še?r râ mi- xânand. boy -pl poem OBJ IMP- read-3sg. The boys read the Poem.

(20) Ali yek nâme mi- nevis- ad. Ali one letter IMP- write -3sg 'Ali writes a letter.'

(21) ân mard yek sigâr mi- keš- ad. that man one cigarette IMP-somke-3sg 'That man smokes a cigarette.'

Sentences (16-18) show different properties comparing with those of (19-21). Sentences (16-18) having a non-referential second argument are compatible with test 4 (for an hour) but sentences (19-21) are not.

(16.a) Pesar-hâ yek sâ?at še?r mi-xân-and.

'The boys read poetry for an hour.'

(19.a) * Pesar-hâ barây yek sâ?at še?r râ mixân-and.

'The boys read the poem for an hour.'

(17.a) Ali barây yek sâ?at nâme minevisad. 'Ali does letter-writing for an hour.'

(20.a) *Ali barây yek sâ?at yek nâme mi-nevisad.

'Ali writes a letter for an hour.'

Sentences (19.a) and (20.a) show that when the second arguments of activity predicates take a specificity marker such as the postposition - $r \hat{a}$, the quantity marker yek, etc their Aktionsart will be changed. Indeed, (19a) and (20 a) are the accomplishment uses of their activity counterparts. It is noteworthy that these sentences are compatible with adverbs denoting accomplishments (Karimi 2001). Thus,,test 5 is compatible with verbs having a referential second argument.

(22) Pesar-hâ dar yek sâ?at še?r râ xândand.

'The boys read the Poem in an hour.'

(23) Ali dar Panj daqiqe yek nâme nevešt.

'Ali wrote a letter in five minutes.'

Another difference between predicates having non-referential arguments and those with referential ones is that non-referential arguments can not be separated from the verb but referential arguments can (Dabirmoghaddam, 1996). 
Mahootian (1997, p. 6) states that when a prepositional phrase is present in the sentence, it typically occurs between the subject and the direct object but if the direct object is definite a variation of word order can take place. A definite direct object, which is marked with the object marker -râ can occur before the prepositional phrase. For example, in sentences (19-21) repeated here as (24) and (26), a noun phrase such as a benefactive' a recipient, or an adverb can be appeared between the argument and the verb. On the contrary, this is not possible for sentences (16-18)repeated here as(25)and(27).

(24) Pesar -hâ še?r râ barây mâ xând-and. boy -pl poem OBJ for us read-3pl. 'The boys read the poem for us.'

(25) *Pesar -hâ še?r barây mâ mixânand. boy -pl poem for us read-3pl 'The boys read poetry for us.'

(26) Pesar -hâ še?r râ zud xândand. boy -pl poem OBJ soon read-3pl 'The boys read the poem soon.'

(27)* Pesar -hâ še?r zud xândand. boy -pl poem soon read-3pl 'The boys read poetry soon.'

The ungrammaticality of (25) and (27) shows that the non-referential arguments can not be separated from the verb, but they have to be adjacent to it. It is a good piece of evidence in support of the idea that considers the non-referential arguments as part of the predicate, i.e inherent argument. In fact, these arguments are not considered as participants in the event.

Another difference between referential and non-referential arguments of activity predicates is that they can not appear together in a coordination construction.

(28) Man yek nâme va in maqâle râ neveštam. $1 \mathrm{sg}$ a letter and this paper OBJ write-PAST-Sg.

'I wrote a letter and this paper.'

(29) Man nâme va maqâle neveštam. $1 \mathrm{sg}$ letter and paper write-1sg 'I wrote letters and papers.'

(30) *man nâme râ va maqâle neveštam. $1 \mathrm{sg}$ letter OBJ and paper write-1sg.

'I wrote the letter and paper.'

In (28) both nâme and maqâle are referential. In (29) both are non-referential. But in (30) one of them nâme is referential and the other maqâle is non-referential. The ungrammaticality of (30) shows that these two arguments don't have identical semantic structure.

Another piece of evidence indicating that non-referential arguments are not objects but inherent arguments of activity verbs, can be deduced from the information structure of transitive and intransitive sentences. Persian has an unmarked SOV word order. However, in transitive sentences, the direct object may occur clause initially and function as a topic (Mahootian, 1997, p. 121, Karimi 2000, Dabirmoghaddam 1991). Of course the object in this initial position may be stressed to indicate narrow focus. As the following sentences show this variability in word order is possible in sentences with a referential objects but not with those including non-referential ones.

(31) Pesar -hâ âwâz râ mi- xânand. boy -Pl song OBJ IMP- read-3Pl 'The boys sing the song.'

(31a) âwâz ra pesar-hâ mi-xânand. song OBJ boy -Pl IMP-read-3Pl. 'It is the song that the boys sing.'

(32) Pesar -hâ âwâz mi- xânand. boy -Pl song IMP- read-3Pl 'The boys sing.'

(32a) *âwâz Pesar -hâ mi- xânand. song boy -Pl IMP-read-3Pl.

In (31) âwâz 'song' is a referential argument taking the postposition-râ. This sentence can be uttered as (31.a) in which the object is separated from the verb and topicalized. On the other hand, in (32) âwâz is non-referential and as (32.a) shows this kind of variation of word order is not possible. In my view, it can be concluded that non-referential second arguments of activity verbs are not objects because they can not separated from the verbs like transitive sentences.

Iranian traditional grammarians call the above-mentioned non-referential arguments generic objects (Vahidian 2000, Khanlari 1976, Moin 1990, among others). However, among Iranian linguists two people studied what is called non-referential second argument of activity verbs in this paper. Dabirmoghaddam (1996) in a paper analyzing compound verbs in Persian, paid attention to these non-referential arguments. Since he made no distinction between different verb 
classes in his analysis, he referred to the second arguments of activity predicates as non-referential objects. Then, he has argued that Persian allows incorporation of direct object into the verb. He states that a direct object may lose its referentiality markers and incorporate with the verb to create an intransitive compound verb which is a conceptual whole. He has presented the following examples:

(33) bačče -hâ qazâ râ xord -and.

child -pl food OBJ eat-PAST -3pl.

'The children ate the food.'

(34) bačče -hâ qazâ xord -and

child -pl food eat-3pl

'The children did food-eating.'

He concluded that in (33) the object qazâ 'food' has lost the referentiality marker-râ and incorporated to the verb xordan. It is worth noting that all of examples of incorporation process he presented in his paper, are second arguments of activity verbs. In my view Dabirmoghaddam's findings concerning incorporation substantiate the special treatment of VanValin and LaPolla who have stated that in many languages the inherent argument may or even must be realized as an incorporated noun (P. 150).

In addition to Dabirmoghaddam's analysis, Karimi (2001) in a GB based paper has dealt with specific and non-specific objects, and enumerated the syntactic, morphological and semantic asymmetries between them. Like Dabirmoghaddam, she also made no distinction between verb classes, but all non-specific objects she presented are second arguments of activity predicates. Furthermore, she has argued that non-specific objects are part of the event, rather than the participants in the event and allow a process of compounding with the verb. As a matter of fact, her analysis bears out the notion of innerent argument introduced by VanValin and LaPolla.

\section{Mismatch Between Syntactic And SEmantic Transitivity}

Transitivity is traditionally defined in terms of the number of arguments a verb takes overtly in the syntax, but RRG makes a distinction between syntactic and semantic transitivity (VanValin and LaPolla, 1997, p. 150). According to them transitivity depends on the number of macrorole a verb takes. Single macrorole verbs are intransitive and two macrorole verbs are transitive. Because of the non-identity of semantic and syntactic valence, transitivity cannot be characterized in terms of the number of syntactic arguments, but must be defined in terms of the number of macroroles that a verb takes. Van Valin and LaPolla claimed that the second argument of a two-place activity predicate is necessarily non-referential and therefore takes a non-macrorole value in violation of macrorole assignment prinicple, according to which a verb with two logical structure arguments normally gets two macroroles, actor and undergoer. Now, let's look at (33-34) again repeated here as $(33 a)$ and $(34 a)$ :

(33.a) bačče-hâ qazâ râ xordand.

(34.a) bačče-hâ qazâ xordand.

In (33.a) the undergoer qazâ is a referential argument and the direct object of the verb, but in (34.a) qazâ doesn't refer to any specific food. As Karimi (2001) has stated non-specific objects like qazâ in (32.a) are part of the description of the predicate. Dabirmoghaddam (1996) has argued that non-referential arguments are incorporated into the verb and form a compound verb that functions as a single predicate. Van Valin and LaPolla see this contrast as evidence that the second argument of an activity verb is not un undergoer, but a non-macrorole core argument under the assumption that undergoers must be referential since they refer to the participant primarily affected in the state of affairs. As Dabirmoghaddam (1996) noted compound verbs formed through incorporation are systematically intransitive. It proves the idea that the incorporated argument is not a semantic argument of the verb, but an inherent argument. Hence, two place activity verbs should be regarded as intransitive, because they have only one argument in their logical structures.

\section{CONCLUSION}

It was shown in this paper that activity verbs in Persian fully follow the verb classification and tests for determining verb classes in RRG. I have also examined second arguments of activity predicates and shown that their special characteristics can be explained in a straightforward manner by the proposal presented in Van Valin and LaPolla (1997). I have argued that second arguments in activity verbs of consumption, creation, performance, etc. are not arguments of the verbs but inherent arguments. If these second arguments take a referentiality marker such as the postposition -râ, the indefinite marker /-i/,or a marker of quantity like yek, etc the predicate will be compatible with adverbs denoting accomplishment. It has been shown that the analysis of specific and non-specific objects by Karimi (2001) and noun incorporation by Dabirmoghaddam (1996) provide evidence in support of my suggestion, although they paid no attention to the different verb classes. Finally, this paper supports the contrast made between S-transitivity and M-transitivity Proposed by Narasimhan (1995) and adopted by VanValin and LaPolla.

\section{REFERENCES}

[1] Dabirmoghaddam, M. (1991). About râ in Persian. Iranian Journal of Linguistics 7: 2-61.

[2] Dabirmoghaddam, M. (1996). Compound Verbs in Persian. Proceedings of the Third Linguistics Conference. Allameh Tabatabai 
University. Tehran.67-122.

[3] Dowty, D. (1979). Word Meaning and Montague Grammar. Dordrecht: Reidel

[4] Foley, William A. and Robert D. VanValin, Jr.(1984). Functional Syntax and Universal Grammar. Cambridge University Press.

[5] Karimi, S. (1999).A note on Parasitic Gaps and Specificity. Linguistic Inquiry 30: 704-713.

[6] Karimi, S.(2000) 'Is scrambling as strange as we think it is?,' MIT Linguistics Working Papers (MITLWP). PP 159-190.

[7] Karimi,S . (2001). What are the Syntactic, Semantic, and Morphological Properties of Persian Object NPs? Paper Presented at Workshop on Issues in Persian Linguistics. Azad University at Khorasgan.

[8] Khanlari, P. (1976). Persian Grammar. Tehran: Bonyad-e Farhang-e Iran Press.

[9] Mahootian, Shahrzad. (1997). Persian. Routledge.

[10] Moin,M.( 1990). Esm-e Jens: Generic Nouns, Definite and non-Definite. Tehran: Amirkabir.

[11] Pavey,E.(2010).The Structure of Language. Cambridge: Cambridge University Press.

[12] Vahidian, M.T.( 2000). Persian Grammar, Tehran: SAMT

[13] VanValin, Robert D. Jr. (1999). Cross Linguistic Patterns of Linking. Proceedings of the 1999 Texas Linguistics Society meetings. .

[14] VanValin, Robert D. Jr (2005). Exploring the Syntax- Semantics Interface. Cambridge: Cambridge University Press.

[15] VanValin, Robert D. Jr. and Randy J. LaPolla. (1997). Syntax: structure, meaning and function. Cambridge University press.

[16] Yang, Byong-Seon. (1994). Morphosyntactic Phenomena of Korean in Role and Reference Grammar. PhD Dissertation. State University of New York at Buffalo.

Vali Rezai is Assistant Professor of linguistics at the University of Isfahan, Isfahan, Iran. He received his Ph.D. degree in linguistics from the University of Isfahan in 2003. His primary research interests concern syntactic theories, typology and functional grammar. He has published many articles in Iranian and international journals. 